\title{
A Review: Giving Micronutrients Intervention Zink For The Prevention Of Stunting
}

\author{
Yp Rahayu $^{1}$ *, Sismeri Dona ${ }^{2}$ \\ \{yayupujirahayu@unism.ac.id ${ }^{1}$, sismeridona@unism.ac.id ${ }^{2}$ \} \\ ${ }^{1.2}$ Department of Midwifery, Faculty of Health, University of Sari Mulia, Banjarmasin, \\ Indonesia. \\ * yayupujirahayu@unism.ac.id
}

\begin{abstract}
Stunting in children under five is one pda toddler nutritional problems caused by chronic malnutrition during the pre and post-natal period. The purpose of this review is to examine the provision of micronutrients that affect the prevention of stunting in children under five.
\end{abstract}

Keywords: Intervention, prevention, stunting, zinc,

\section{Introduction}

Stunting is chronic nutritional problems in infants characterized by a shorter stature compared to his age. Children who suffer from stunting are more susceptible to disease and when adults are at risk for degenerative diseases. Stunting impact not only in terms of health but also affect the level of intelligence of children [1].

Indonesia is one country with a double triple nutritional problems include under-nutrition (stunting and wasting), micronutrient deficiencies and obesity. The prevalence of child stunting Indonesia is $37.2 \%$ and is currently about 8 million children in Indonesia has grown not optimal [1].

Based on data from the Nutritional Status Monitoring (PSG) during the last three years, short of having the highest prevalence compared with other nutritional problems such as malnutrition skinny and fat. Short Prevalence increased from 2016 that is $27.5 \%$ to $29.6 \%$ in 2017 [2]. Based on the results of PSG in 2015, the prevalence of short toddler in Indonesia is $29 \%$. The number declined in 2016 to $27.5 \%$ [3]. However, the prevalence of short toddler increased again to $29.6 \%$ in 2017 . The prevalence of very short and short toddlers $0-59$ months of age in Indonesia in 2017 was $9.8 \%$ and $19.8 \%$. These conditions increase from the previous year prevalence of very short infants and toddlers at $8.5 \%$ short of $19 \%$.

Toddler stunting prevalence data collected World Health Organization (WHO), Indonesia is among the three countries with the highest prevalence in Southeast Asia / South-East Asia Regional (SEAR). The average prevalence of stunting infants in Indonesia in 2005-2017 was $36.4 \%$ [4].

International experience and evidence show that stunting can hamper economic growth and reduce the productivity of the labor market, resulting in loss of 11\% of GDP (Gross Domestic Products) as well as reduced income up to $20 \%$ of adult workers. Moreover, stunting can also contribute to widening the gap / inequality, reducing $10 \%$ of the total income 
for life and also lead to inter-generational poverty (10 regencies / Koota Priorities for Intervention Stunted Children [4].

Actually, it has been many efforts made by the government to reduce the rate of stunting in Indonesia. This is evident from the decline in the prevalence of stunting Toddlers from $37.2 \%$ in 2013 to $30.8 \%$ in 2018 . The prevalence of stunting baduta also decreased from $32.8 \%$ in 2013 to $29.9 \%$ in 2018. [5] , But even so, the numbers decline still far from the target. The decline in stunting only 4\% between 1992 and 2013 [6].

Malnutrition caused by a deficiency occurs in addition to the macronutrient intake, can also be caused by a deficiency of the micronutrient intake. Type micronutrients that have known benefits and are vital to the growth and development of the human body is zinc and iron. Zinc $(\mathrm{Zn})$ is an essential micronutrient for humans. These nutrients are nutrients that the second largest after the iron in the human body. Zinc contained in various types of enzymes, nearly 100 enzymes in the body containing zinc $[7,8]$. The function of zinc is an effect on cell growth and division, antioxidants, sexual development, appetite, and has a close relationship with the endocrine system. Therefore, not only a zinc deficiency causes growth retardation, but also a decrease in appetite, delayed sexual maturation, hypogonadism, and thyroid dysfunction. Zinc is mainly needed for the acceleration of growth; this is not only due to the effect of cell replication and nucleic acid metabolism, but also as a mediator of growth hormone activity $[7,8,9]$.

One is the role of micronutrient intake of zinc $(\mathrm{Zn}) . \mathrm{Zn}$ is a nutrient that plays an important role in many bodily functions such as cell growth, cell division, metabolism, immune function and development. Zn supplementation had a significantly positive response to the increase in body weight and height, and can improve stunted linear growth in children [10,11].

\section{Stunting}

Stunting, or being too short for one's age, is defined as a height that is more than two standard deviations below the World Health Organization (WHO) Child Growth Standards median3. It is a largely irreversible outcome of inadequate nutrition and repeated bouts of infection during the first 1000 days of a child's life. Stunting has longterm effects on individuals and societies, Including: diminished cognitive and physical development, reduced productive capacity and poor health, and an Increased risk of degenerative diseases such as diabetes $[12,13]$

Stunting is a well-established risk marker of poor child development. Stunting before the age of 2 years Predicts poorer cognitive and educational outcomes

in later childhood and adolescence and has significant educational and economic consequences at the individual, household and community levels. where adults who were stunted at age 2 completed nearly one year less school than non-stunted individuals $[14,15,16,17]$

\section{Pathogenesis of Stunting}

Stunting occurs from pre-conception when a teenager becomes mother malnutrition and anemia. Become severe during pregnancy with inadequate nutrient intake needs, plus more when mother living in an environment with inadequate sanitation.

Stunting syndrome is indicated by the figure below; 


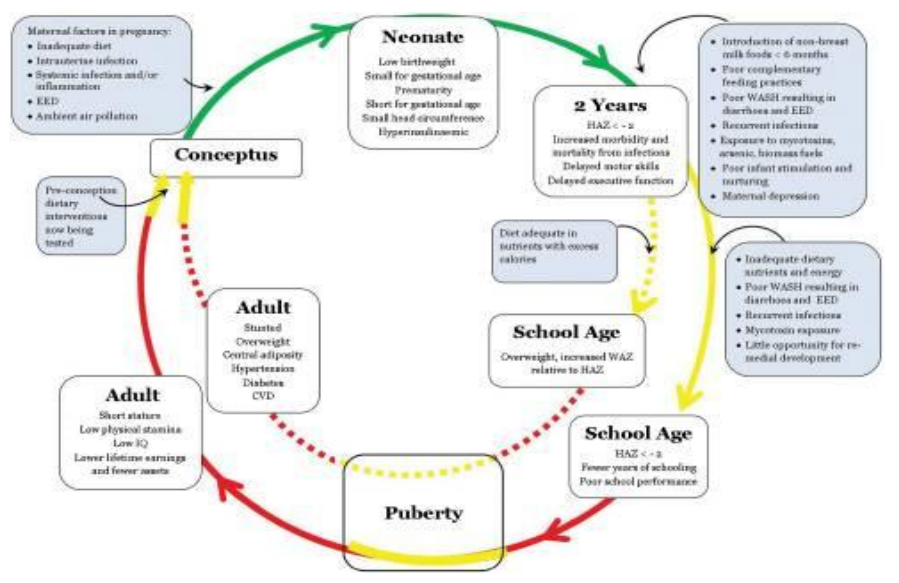

In the picture above is explained that Green line shows the period between conception and 2 years ( '1000' first day ') when stunting and probably all related pathologies most responsive to or prevented with intervention. Yellow line indicates the period between the age of 2 years and mid-childhood and during the growth spurt teenager when some catch-up in linear growth can occur, although the effect during this period to other components of the syndrome of stunting (eg, cognitive function and immunity) is less clear , Short yellow lane before Conceptusmencerminkan evidence that dietary interventions targeting pygmy women during the pre-conception improve birth outcomes. the red line indicate the period when stunting syndrome appears unresponsive to interventions. Blue box lists the factors that cause or aggravating age-specific. White box describes the results of a specific age public. Between 2 years and adults, different paths with: the dotted line, a dwarf child becomes more affluent environment with abundant food access, leading to excessive weight gain; Solid line: a dwarf child that the environment remains limited resources / food insecurity.

Food insecurity is often the case based on the image above is the drawback of nutrients micronutrients. Some micronutrients are often deficient in the body is deficiency of vitamin $\mathrm{A}$, zinc, iron and iodine are common and some micronutrient deficiencies often found in the same children, affecting many aspects of physiology, including the nervous and immune function. Globally, two billion people are at risk of micronutrient deficiencies, the so-called 'hidden hunger' because of its impact on the health and human resources. A systematic review found the micronutrient powders are relatively few studies that evaluate growth; no one advised benefits and no increase in diarrhea in some children taking the micronutrient powder $[18,19,20,21]$.

\section{Zinc Interventions for The Prevention of Stunting}

Stunting prone to happen at the age of 0-2 years or under the age of three years (toddlers) is the golden period (golden age) for the growth and development of children, because at that time happened very rapid growth. The first period of 1,000 days is often called the window of opportunities or golden period is based on the fact that in the fetus until the 
child is two years of age there is a process for growing up very fast and does not occur in other age groups. Failure to thrive in this period will affect the nutritional status and health in adulthood.

Intervention by taking into account parenting and indispensable diet in the prevention of stunting. Feeding patterns that be the discussion in this review is the provision of zinc / zinc.

Zinc plays a role in many cellular processes as a cofactor of various enzymes and the effect on gene expression through transcription factors. General zinc plays a role in growth to contribute to the growth hormone synthesis, synthesis of DNA and RNA [22]. Growth hormone plays a role in growth is the Insulin Like Growth Factor-1 (IGF-1). Insulin Like Growth Factor has a function to enhance cell growth [23]. Zinc plays a role in growth hormone synthesis, secretion, and the production of IGF-1 in the liver. Zinc is also involved in the activation of IGF-1 in bone cartilage. Zinc deficiency is closely related to the reduced synthesis and activity of IGF-1. Growth disorders can occur starting from the time of pregnancy. Zinc depletion light levels during pregnancy is closely associated with impaired fetal growth [24]. Results of the study also noted that supplementation multiple micronutrients during pregnancy (one of which is zinc) resulted in an increase in height and decrease body fat measured with lean muscle mass in children aged 6-8 years [25]. The results of this study to make growth in school age children need special attention early because closely related to the development of intelligence and productivity as adults [26].

\section{Conclusion}

Based on the results of the study showed that $\mathrm{Zn}$ supplementation should be considered in nutrition treatment programs, especially the occurrence of stunting in children

\section{Reference}

[1]. Anonymous, (2018), Bulletin of the window of data and health information. ISSN 2088-270x

[2]. MoH, 2017. Handbook of Nutrition Status Monitoring (PSG). Jakarta

[3]. MoH, 2016. Handbook of Nutrition Status Monitoring (PSG). Jakarta

[4]. Toddlers situation Short (Stunting) in Indonesia, Issue 1 Semester 12018 (Bulletin of Data and Information Window of Health 2018).

[5]. Satriawan, E. (2018). The National Strategy to Accelerate Prevention Stunting 20182024. Jakata: National Team to Accelerate Poverty (TNP2K).

[6]. Aryastami, NK (2017). Policy Assessment and Countermeasures Stunting Nutrition Problems in Indonesia. Health Research Bulletin 45 (4), 233-240.

[7]. Masayuki Nishi K \& Y. 2006. Growth and Minerals: Zinc. On line. Journal of the American Coll Nutr, Vol. 22, Issue 1. www.gghjournal.com.

[8]. Ridwan, Endi. 2012. Study of Interaction Iron With Micro nutrient substances Others In supplementation. Penel Nutrition Spot, 2012, 35 (1): 49-54

[9]. Sareen S. Gropper, Jack L. Smith, James L, Groff. 2009. Advanced Nutrition and Human Metabolism, 5 th Edition. Wadsworth, Cengage Learning. USA 
[10]. Brown KH, Peerson JM, Rivera J, Allen LH. Effect of supplemental zinc on the growth and serum zinc concentrations of prepubertal children: a meta-analysis of randomized controlled trials. Am J Clin Nutr. 2002; 75: 1062-71.

[11]. Shankar AH, AS Prasad. Zinc and immune function: the biological basis of Altered resistance to infection. Am J Clin Nutr. 1998; 68 (Suppl.2): S447-63.

[12]. World Health Organization (WHO) Child Growth Standards: http: // www. who.int/childgrowth/en/.

[13]. The state of the world's children 2013. Children with Disabilities. New York: United Nations Children's Fund; 2013 (http://www.unicef.org.uk/ Documents / Publicationspdfs / sowc-2013-children-with-disabilities.pdf

[14]. Walker SP, Chang SM, Powell CA, Simonoff E, Grantham-McGregor SM. Early childhood stunting is associated with poor psychological functioning in late adolescence and effects are reduced by psychosocial stimulation. J Nutr. 2007; 137: 2464-9.

[15]. Black RE, Victora CG, Walker SP, Bhutta ZA, Christian P, de Onis M, et al .; the Maternal and Child Nutrition Study Group. Maternal and child undernutrition and overweight in low-income and middle-income countries. Lancet 2013; 371: 243-60. doi: 10.1016 / S0140-6736 (13) 60 937-X.

[16]. Martorell R, Horta BL, Adair LS, Stein AD, Richter L, Fall CH et al. Weight gain in the first two years of life is an important predictor of schooling outcomes in pooled analyzes from five birth cohorts from low- and middle-income countries. J Nutr. 2010; 140: 348 54. doi: 10.3945 / jn.109.112300.

[17]. Adair LS, Fall CHD, Osmond C, Stein AD, Martorell R, Ramirez-Zea M et al .; Cohorts Group. Associations of linear growth and relative weight gain during early life with adult health and human capital in countries of low and middle income: findings from five birth cohort studies. Lancet. 2013; 382: 525-34. doi: 10.1016 / S0140-6736 (13) 60103-8.

[18]. Black RE, Allen LH, Bhutta ZA, Caulfield LE, de Onis M, Ezzati M, et al. Maternal and child undernutrition: global and regional exposures and health consequences. Lancet. 2008; 371: 243-60.

[19]. Abu-Saad K, Fraser D. Maternal nutrition and birth outcomes. Epidemiol Rev. 2010; 32: $5-25$.

[20]. Muthayya S, Rah JH, JD Sugimoto, Roos FF, Kraemer K, Black RE. The global indices and maps hidden hunger: an advocacy tool for action. PLoS One. 2013; 8: e67860

[21]. Greeting RA, MacPhail C, Das JK, Bhutta ZA. BMC Public Health. (Suppl 3) Vol. 13. S22; 2013. Effectiveness of micronutrient powders (MNP) in women and children. doi: 10.1186 / 1471-2458-13-S3-S22.

[22]. Lee YJ, Lee CY, Grzechnik A, Gonzales-Zubiate F, Vashisht AA, Lee A, Wohlschlege J, Chanfreau GF. 2013. RNA polymerase I couples stability of cellular growth to metal availability. Molecular Cell 51 (1): 105-115

[23]. Maggio M, De Vita F, Lauretani F, Butto V, Bondi G, Cattabiani C, Nouvenne A, Meschi

T, Dall'Aglio E, Ceda GP. 2013. IGF-1, the cross road of the nutritional, inflammatory and hormonal pathways to Frailty. Nutrients 5 (10): 4184-4205.

[24]. Christian P, Stewart CP. 2010. Maternal micronutrient deficiency, fetal development, and the risk of chronic disease. J Nutr 140 (3): 437- 442. 
[25]. Stewart CP, Christian P, LeClerq SC, West KP Jr, Khatry SK. 2009. Antenatal supplementation with folic acid + iron + zinc improves linear growth and Reduces peripheral adiposity in school-age children in Rural Nepal. Am J Clin Nutr 90 (1): 13240.

[26]. Black MM. 2003. The evidence linking zinc deficiency with children's cognitive and the motor functioning. J Nutr 133 (Suppl 5): 1473S1476S. 